\title{
Ashinkailepas kermadecensis, a new species of deep-sea scalpelliform barnacle (Thoracica: Eolepadidae) from the Kermadec Islands, southwest Pacific
}

\author{
JOHN S. BUCKERIDGE
}

Earth \& Oceanic Systems Research Group, RMIT University, Melbourne, VIC 3001, Victoria, Australia.

E-mail: john.buckeridge@ rmit.edu.au

\begin{abstract}
A new deep-sea stalked barnacle, Ashinkailepas kermadecensis sp. nov. has been recovered from a cold-water seep at depths of 1165 metres in the vicinity of the Kermadec Ridge to the northeast of the North Island, New Zealand. There are now two species of Ashinkailepas - the other, Ashinkailepas seepiophila Yamaguchi, Newman \& Hashimoto, 2004, occurs in deep, cold seeps off central Japan. As there are two species within Ashinkailepas, formal diagnoses are provided for both taxa.
\end{abstract}

Key words: Crustacea, Cirripedia, Scalpelliformes, Ashinkailepadini, cold seep taxa

\section{Introduction}

The discovery of a unique deep-sea biota associated with the hydrothermal vents to the NE of New Zealand, along the Kermadec Ridge-Trench complex, was first made in the late 1990s during the NZAPLUME Cruise (de Ronde et al., 1999). Of interest here is the neolepadine barnacle Vulcanolepas osheai (Buckeridge, 2000), the first living eolepadid recorded from the region. Since then further collection from the Kermadec area, but from cold seeps, has resulted in recovery of this new barnacle. Cold seeps (or cold vents) differ from hydrothermal vents in that they are less volatile systems, with lower temperature fluids, including hydrocarbon gases such as methane. Newman (1985) proposed that the habitat provided by hydrothermal vents and cold seeps is refugial, wherein taxa may persist for greatly extended periods of time. This interpretation has been borne out by the disproportionately large number of primitive taxa that have subsequently been found in these habitats (e.g. Southward \& Jones, 2003; Yamaguchi et al., 2004; Southward, 2005)

Institutional abbreviations: NIWA-National Institute of Water and Atmospheric Research, Wellington, New Zealand; NMV—Museum Victoria, Melbourne, Victoria, Australia.

\section{Systematics}

\section{Subclass CIRRIPEDIA Burmeister, 1834}

\section{Superorder THORACICA Darwin, 1854}

Remarks. Buckeridge \& Newman (2006) revised the systematics of the Thoracica to include four very distinct orders; of these the Scalpelliformes, which have the greatest morphologic and geographic diversity of 